\title{
Antigen Targets of Type 1 Diabetes Autoimmunity
}

\author{
Bart O. Roep ${ }^{1}$ and Mark Peakman ${ }^{2,3}$ \\ ${ }^{1}$ Department of Immunohematology and Blood Transfusion, Leiden University Medical Center, 2333 Leiden, \\ The Netherlands \\ ${ }^{2}$ Department of Immunobiology, King's College London, School of Medicine, London SE1 9RT, United Kingdom \\ ${ }^{3}$ National Institute of Health Research Biomedical Research Centre at Guy's and St Thomas' \\ NHS Foundation Trust and King's College London, London SE1 9RT, United Kingdom \\ Correspondence: mark.peakman@kcl.ac.uk
}

Type 1 diabetes is characterized by recognition of one or more $\beta$-cell proteins by the immune system. The list of target antigens in this disease is ever increasing and it is conceivable that additional islet autoantigens, possibly including pivotal $\beta$-cell targets, remain to be discovered. Many knowledge gaps remain with respect to the disorder's pathogenesis, including the cause of loss of tolerance to islet autoantigens and an explanation as to why targeting of proteins with a distribution of expression beyond $\beta$ cells may result in selective $\beta$-cell destruction and type 1 diabetes. Yet, our knowledge of $\beta$-cell autoantigens has already led to translation into tissue-specific immune intervention strategies that are currently being assessed in clinical trials for their efficacy to halt or delay disease progression to type 1 diabetes, as well as to reverse type 1 diabetes. Here we will discuss recently gained insights into the identity, biology, structure, and presentation of islet antigens in relation to disease heterogeneity and $\beta$-cell destruction.

\section{IDENTIFICATION OF AUTOANTIGENS IN TYPE 1 DIABETES}

$\mathrm{T}^{\mathrm{h}}$ he pancreatic $\beta$ cell is ranked among the most specialized cells in the human body. In addition to the vital production, storage, and secretion of insulin, to which end a range of $\beta$-cell-specific proteases act in concert, these cells are also capable of sensing and responding to changes in glycemia. These unique metabolic attributes have proven extremely challenging to mimic with artificial devices, limiting the full potential of current hormone replacement therapy. Not surprisingly, many proteins have been identified that are selectively or preferentially expressed by $\beta$ cells, and, to varying degrees, many of these proteins have been shown to be potential targets of the immune system, with downstream implications for the etiology of type 1 diabetes (Harrison 1992; Roep et al. 1996; Di Lorenzo et al. 2007). Indeed, a single, primary autoantigenic target, if it exists, remains to be identified with certainty.

At the earliest stages of research in this arena, the discovery of islet autoantigens was guided by their recognition by islet cell autoantibodies (ICAs). Since the identification of ICAs in 1976, their target $\beta$-cell proteins have been

Editors: Jeffrey A. Bluestone, Mark A. Atkinson, and Peter R. Arvan

Additional Perspectives on Type 1 Diabetes available at www.perspectivesinmedicine.org

Copyright (C) 2012 Cold Spring Harbor Laboratory Press; all rights reserved; doi: 10.1101/cshperspect.a007781

Cite this article as Cold Spring Harb Perspect Med 2012;2:a007781 
revealed little by little, albeit with a very slow pace and still incompletely (Bottazzo et al. 1974; Baekkeskov et al. 1990; Miyazaki et al. 1994; Martin et al. 1995; Payton et al. 1995). With the exception of insulin as an obvious candidate, it took until 1990 to discover the nature of the $64 \mathrm{kDa}$ protein precipitated by ICAs as glutamate decarboxylase (GAD) (Baekkeskov et al. 1990). There are two genes coding for largely homologous enzymes of 65 and $67 \mathrm{kDa}$ molecular mass (GAD65 and GAD67, respectively), the latter thought to be less antigenic and less relevant to type 1 diabetes (Karlsen et al. 1992). Several other targets of autoantibodies have been identified since, including carboxypeptidase $\mathrm{H}$, the tyrosine phosphatase-like proteins insulinoma antigen-2 (IA-2) and IA$2 \beta$ (also termed phogrin or ICA512) (Atkinson and Maclaren 1993; Payton et al. 1995; Kawasaki et al. 1996).

With the premise that type 1 diabetes is caused by islet autoreactive $\mathrm{T}$ cells, rather than ICAs, it is conceivable that additional target autoantigens exist that may not be revealed by the same antibody-guided strategy, either because they are not recognized by ICAs or because the titer of autoantibodies is below conventional detection levels. Indeed, approaches to identify CD4 T-cell targets directly led to the discovery of imogen-38 and islet-specific glucose-6-phosphatase catalytic subunit-related protein (IGRP) as $\beta$-cell autoantigens, despite a lack of data (then or now) on existing humoral immune responses to these proteins (Roep et al. 1990, 1991; Arden et al. 1996; Han et al. 2005).

A third approach to identify $\beta$-cell autoantigens involved a cell biological strategy based on selective expression of $\beta$-cell proteins as defined by complementary DNA (cDNA) subtraction libraries or microarrays (Miyazaki et al. 1994; Arden et al. 1996; Neophytou et al. 1996). In retrospect, proteins that were initially identified through their stimulation of autoimmune responses (imogen-38, IGRP, IA-2, and IA-2ß) were confirmed by these experiments, whereas new candidates were identified that subsequently proved to be relevant and potentially associated with the immunopathogenesis of type 1 diabetes, such as ICA69 and most recently the zinc transporter 8 (ZnT8) (Wenzlau et al. 2010).

Finally, in a process of "inverse translation," animal models have confirmed a pathogenic role for several $\beta$-cell autoantigens (GAD65, insulin; for example, via adoptive transfer of specific T cells, or expression knock-down) and delivered some new targets that either remain relevant for autoimmune diabetes in mice (peripherin) or remain to be validated in clinical disease (chromogranin A); equally, the relevance of autoantigens that are important in humans remains to be established for autoimmune diabetes in mice (e.g., IA-2) (Kash et al. 1999; Moriyama et al. 2003; Faideau et al. 2004). For the record, the major preclinical model of spontaneous autoimmune diabetes, the nonobese diabetic (NOD) mouse, at present only shows convincing evidence for ICAs against insulin, precluding discovery of additional islet autoantigens via demonstration of humoral autoimmunity (Roep et al. 2004). Intriguingly, in this model, the antigen specificities of T cells isolated from inflamed pancreatic islets (insulitis) appear to be different from those of spleen. CD4 $\mathrm{T}$ cells specific for insulin and CD8 T cells specific for IGRP seem predominantly present in insulitic lesions, whereas analysis of the spleen reveals $\mathrm{T}$ cells with other specificities (chromogranin A, islet amyloid polypeptide [IAPP], and unknown $\beta$-cell targets) (Haskins et al. 1989; Wegmann et al. 1994; Stadinski et al. 2010; Delong et al. 2011).

\section{MECHANISMS UNDERLYING THE LOSS OF TOLERANCE TO ANTIGENS IN TYPE 1 DIABETES}

Different components and mechanisms of the immune system determine autoimmunity (Fig. 1). T cells reactive with self-antigens are believed to be eliminated by apoptosis in the thymus in a process referred to as central tolerance. In the thymus, the transcription factor AIRE (autoimmune regulator) is expressed in the medulla controlling transcription of a wide selection of organ-specific genes (including, for instance, preproinsulin) that generate proteins that are usually only expressed in peripheral tissues, 
$\beta$-Cell Antigens and Disease

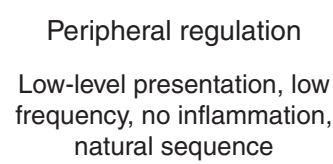

Figure 1. Representation of the role of $\beta$-cell autoantigens in the development of type 1 diabetes. Thymic events that predispose to impaired tolerance to $\beta$-cell proteins include low-level expression or presentation, crypticity, and low affinity. In the periphery, thymic escapee T cells with autoreactive potential are more likely to be primed when expression of the antigen is high, presentation is enhanced, and there is inflammation, perhaps concomitant with the presence of neo- or altered epitopes. Peripheral regulation is fostered by controlled expression of the autoantigen, in the absence of inflammation, using low-frequency exposure to native sequences.

creating an "immunological self-shadow" in the thymus (Anderson et al. 2002). This should, theoretically at least, be sufficient to enable exclusion of autoreactive T lymphocytes. Yet, many $\mathrm{T}$ cells with autoreactive potential evidently slip through the thymus unharmed. It is not completely clear which factors contribute to the incomplete clearance of self-reactive $\mathrm{T}$ cells in the thymus, but this may relate to low binding affinity of self-peptide epitopes to human leukocyte antigen (HLA), low avidity of the T-cell receptor recognizing self-epitope in the context of HLA, and differences in posttranscriptional and posttranslational expression regulation in peripheral tissue versus thymus, as discussed below.

A backup mechanism controlling self-reactivity in the periphery is in place, referred to as peripheral tolerance, that involves regulation of autoreactivity by naturally occurring, nonspecific, and autoantigen-specific regulatory $\mathrm{T}$ cells (Treg). Because tissue cells only express major histocompatibility complex (MHC) class I molecules, direct recognition of tissue cells by the immune system occurs through presentation of self-epitopes on MHC class I molecules to CD8 $\mathrm{T}$ cells, but following removal and processing of tissue cell debris, autoantigenic fragments can also be expressed and presented by macrophages and dendritic cells to both CD4 and CD8 $\mathrm{T}$ cells in the pancreas-draining lymph nodes (through a process referred to as crosspresentation in the case of CD8 T cells). Consequently, both CD4 and CD8 T cells may contribute to both autoreactivity and the control thereof.

It is unclear which factors are involved in loss of tolerance to $\beta$-cell antigens in type 1 diabetes, but it has become evident that the $\beta$ cell is actively involved in its own demise, rather than behaving as an innocent victim of immune aggression (Eizirik et al. 2009). Viral infection or endoplasmic reticulum (ER) stress may lead to abnormal immunogenicity of $\beta$ cells, leading to "danger" signals requiring activation of the immune system. Interestingly, one of the first abnormalities in pancreatic islets that seems to precede infiltration of leukocytes (insulitis) is 
hyperexpression of HLA class I and expression of cytokines of the innate immune system, such as interferon- $\alpha$ (possibly pointing to viral infection) and the chemokine CXCL10, attracting immune cells expressing its receptor CXCR3 into the islet microenvironment (Stewart et al. 1993; Willcox et al. 2009; Roep et al. 2010). Presentation of islet antigen to the immune system may be followed by activation of additional $\mathrm{T}$ cells with different islet antigen specificities (determinant or epitope spreading) (Tisch et al. 1993). It does not yet appear the case that there is a single primary islet antigen driving the autoimmune process in type 1 diabetes, nor is it known which islet antigens lead to pathogenic autoreactivity or bystander islet autoimmunity (Achenbach et al. 2005; Steck et al. 2011).

In terms of repertoire of (candidate) autoantigens, it is still a mystery why loss of tolerance to certain proteins expressed in islets as well as other tissues leads to tissue-specific pathology and disease. Whereas type 1 diabetes shows comorbidity with other inflammatory conditions, such as thyroiditis, celiac disease, Sjögren's syndrome, and Addison's disease, the vast majority of patients show islet destruction only. Yet, all known islet autoantigens are expressed elsewhere: preproinsulin (PPI) and IGRP are also expressed in the thymus; GAD65 and IA-2 are neuroenzymes expressed variably in the CNS, neurons, testis, and ovary; chromogranin $A$ is expressed in neurons and non- $\beta$ endocrine cells, and heat shock protein 60 is expressed in all cells carrying mitochondria. Perhaps even more of an enigma, murine $\beta$ cells do not express GAD65, yet, immunotherapy with this protein prevents autoimmune diabetes (Karlsen et al. 1992; Kaufman et al. 1993). Whatever the mechanism, tolerance is broken and there follows activation and recruitment of cohorts of $\mathrm{T}$ lymphocytes recognizing islet autoantigens, which have an intricate involvement in the disease process.

\section{Targets of CD4 T Cells}

The autoreactive CD4 T cell is likely at the heart of this disease, as orchestrator of the immune attack on the $\beta$ cell. It seems most probable and plausible that the breaking of CD4 T-cell tolerance to $\beta$-cell autoantigens is the key step on the pathway to disease. Several strategies have been applied to the investigation of CD4 $\mathrm{T}$ cells in type 1 diabetes, notably candidate autoantigen-driven cloning of $\mathrm{T}$ cells from the peripheral blood, as well as a variety of approaches to measure autoantigen-directed $\mathrm{T}$ cell reactivity in blood samples immediately ex vivo (Atkinson et al. 1992; Durinovic-Bello et al. 1996; Hawkes et al. 2000; Schloot et al. 2007). To date, these approaches have offered important but limited data on antigens and epitopes. Cloning strategies have enabled numerous incisive mechanistic studies to be performed, but the reliance of this approach on the proliferative capacity of cells may lead to an inherent bias in the information it provides regarding cell type, epitopes, and HLA restriction elements. The opportunity to identify potential early or subdominant epitopes is also limited by this approach. Measurement of reactivity in blood samples ex vivo has been performed using whole antigen preparations, although these have well-documented nonspecific effects, or using panels of overlapping peptides (Roep et al. 1991; Brooks-Worrell et al. 1996; Schloot et al. 1997; Dang et al. 2011). The latter approach is successful when test and control populations are well matched, but it provides limited information as to HLA restriction elements, requires excessive volumes of blood for optimal performance, largely restricting its use to adult patients, and has the potential to mask or miss subtle issues of peptide length and register, according to the design of the overlapping peptide set. It is also inherently biased in its outcome by the nature of the method (e.g., proliferation) used to measure responses.

For these reasons, we contend that understanding the role of CD4 T cells in type 1 diabetes and translating this into tissue-specific immunotherapy requires a systematic dissection of the autoimmune T-cell response, addressing the nature of the epitopes targeted, their restriction elements, and the functional and phenotypic characteristics of responder $\mathrm{T}$ cells, as well as their frequency and temporal dynamics (Peakman et al. 1999, 2001; Arif et al. 2004). One of the 
problems in systematizing these studies is the interdependence of several of the parameters involved; for example, studying the frequency of autoreactive $T$ cells may require knowledge about epitopes, HLA restriction, and functional responder type. As a consequence, although the CD4 T cell has been the object of numerous studies in type 1 diabetes, the overall advances in understanding have been modest.

\section{Targets of CD8 T Cells}

It is becoming increasingly clear that $\beta$-cellspecific $\mathrm{CD}^{+} \mathrm{T}$ cells play a pivotal role in the destruction process and constitute a significant portion of insulitis (Bottazzo et al. 1985; Panina-Bordignon et al. 1995; Pinkse et al. 2005; Ouyang et al. 2006; Mallone et al. 2007; Skowera et al. 2008; Willcox et al. 2009; Velthuis et al. 2010). To draw from animal models, NOD mice lacking expression of MHC class I are resistant to autoimmune diabetes, and HLA$A^{*} 0201$ transgenic NOD mice develop accelerated disease (Takaki et al. 2006). Additionally, transfer of $\mathrm{CD}^{+}{ }^{+}$-cell clones results in transfer of type 1 diabetes and tetramer-guided measurement of such cells in the blood has provided a predictive biomarker in mice (Trudeau et al. 2003, 2007). Thus, detection and monitoring of specific CD8 $\mathrm{T}$ cells may provide valuable tools to assess disease activity in man.

The epitopes identified to date for type 1 diabetes-specific human autoreactive CD8 T cells are primarily derived from $\beta$-cell antigens. Among the most important appear to be those from pre- ( pro-) insulin (Pinkse et al.2005; Toma et al. 2005, 2009; Skowera et al. 2008). Previously, we showed that the presence of CD8 T cells reactive to the naturally processed insulin peptide $\mathrm{B}_{10-18}$ presented by HLA-A 2 correlates with islet cell destruction, because increases in numbers of circulating CD8 T cells against insulin $\mathrm{B}_{10-18}$ are increased in type 1 diabetic islet allograft recipients that subsequently lose graft function and insulin independency (Pinkse et al. 2005). Recently, the signal peptide of preproinsulin (the 10-mer peptide ALWGPDPAAA; $\mathrm{PPI}_{15-24}$ ) was uncovered as being a naturally produced and presented HLA-A2 epitope (Sko- wera et al. 2008). Cytotoxic CD8 T lymphocytes (CTL) against this peptide were cloned and killed $\beta$ cells in vitro in a glucose concentrationdependent fashion, linking $\beta$-cell immunogenicity with its functional activity. This finding underscores the relevance of CD8 T-cell islet autoreactivity in the pathogenesis of T1D, whereas it also indicates that $\beta$ cells are actively involved in their own demise. Interestingly, this PPI epitope provided high sensitivity and specificity in terms of frequent and preferential recognition by $\mathrm{T}$ cells from type 1 diabetes patients versus healthy subjects. The peptide appears to be cotranslated with HLA, and as a consequence this peptide-HLA complex showed the property of glucose regulation. Future studies should address whether this model is generally true for other epitopes derived from preproinsulin or other reported $\beta$-cell-derived antigens (e.g., GAD65, IA-2, IGRP, and preproIAPP) (Ouyang et al. 2006; Velthuis et al. 2010). A further intriguing aspect to the PPI studies is that an 8mer peptide that coterminates with $\mathrm{PPI}_{15-24}$ (WGPDPAAA; $\mathrm{PPI}_{17-24}$ ) was also eluted from HLA-A2 and induced CD8 T-cell interferon- $\gamma$ responses when added to patients' peripheral blood mononuclear cells in vitro; and yet, this peptide has no measurable binding affinity for HLA-A2 in vitro, and as a result cannot be loaded into HLA-A2 multimers to investigate the autoreactive CD8 T-cell repertoire (unpublished observations). This illustrates the limitations to our understanding of the immunobiology of an autoimmune disease such as type 1 diabetes, when our approach and technologies are wholly shaped by those used to investigate infectious diseases, in which antigen-receptor interactions are typically high affinity/avidity.

Ideally, monitoring for the presence of $\mathrm{CD}^{+}$ $\mathrm{T}$ cells reactive to all the above-mentioned epitopes simultaneously would be desired, posing considerable constraints on blood volumes accessible for monitoring of islet autoimmunity with conventional immune assays (Velthuis et al. 2010). Initial approaches to monitoring of CD8 T cells reactive to $\beta$-cell-derived antigens required staining of a large number of, usually fresh, cells with HLA tetramers loaded with a single peptide, or in vitro culture for 
functional immune assays (proliferation, cytokine production [ELISPOT]) (Roep et al. 1999; Peakman et al. 2001; Schloot et al. 2003). Furthermore, such detection of islet autoreactive $\mathrm{T}$ cells is hampered by their low precursor frequencies in the circulation, the broad possible range of candidate epitopes, the putative existence of regulatory $\mathrm{T}$ cells, and finally, as discussed above, the probable low binding affinity of peptide epitopes for HLA and low T-cell receptor (TCR) affinity for peptide-HLA (Naik et al. 2004; Ouyang et al. 2006; Velthuis et al. 2010; Unger et al. 2011). To cope with these limitations, new approaches have been developed for simultaneous detection of multiple islet cellspecific $\mathrm{CD}^{+}$T-cell responses, using multidimensional HLA class I multimers. Using this approach the sensitivity and specificity of previously reported HLA-A2 restricted epitopes were determined in recent onset type 1 diabetes patients, their siblings, control blood donors, and islet cell transplant recipients (Velthuis et al. 2010). Frequencies of CD8 T cells reactive with insulin $\mathrm{B}_{10-18}, \mathrm{PPI}_{15-24}$, $\mathrm{IGRP}_{265-273}$, GAD65 $_{114-123}$, ppIAPP $5-13$, and IA- $2_{797-805}$ were found to be significantly increased in the circulation of recent-onset patients, whereas healthy subjects rarely showed autoreactive $\mathrm{CD}^{+}{ }^{\mathrm{T}}$-cell frequencies $>1 / 10,000 \mathrm{CD} 8 \mathrm{~T}$ cells in peripheral blood. Nonetheless, direct ex vivo responses as detected by HLA multimers often contrast with reports using functional assays, such as ELISPOT. This may partly reflect differences in activation status, as well as features influenced by in vitro phenomena during culture.

Functional studies on the engagement of $\mathrm{T}$ cells with these epitopes are less extensive (Ouyang et al. 2006; Unger et al. 2011). The relevance of insulin $\mathrm{B}_{10-18}$ in type 1 diabetes is underlined by observations that peripheral blood mononuclear cell cultures (PBMC) from a type 1 diabetic patient produced IFN- $\gamma$ in response to this peptide, that expression of insulin $\mathrm{B}_{10-18}$ renders target cells sensitive to killing by CTL lines, and most importantly, that the presence of insulin $\mathrm{B}_{10-18}$ specific $\mathrm{CD} 8^{+} \mathrm{T}$ cells correlates with destruction of $\beta$ cells (Pinkse et al. 2005). Even though it cannot be excluded that some of the T-cell reactivity to this particular epitope results from priming by exogenous therapeutic insulin containing this motif, the epitope is naturally processed and presented by $\beta$ cells, rendering these as targets for autoimmune mediated cytolysis (Pinkse et al. 2005).

It remains possible that not all of the $\beta$-cell specificities that are detected as being recognizable by CD8 $\mathrm{T}$ cells represent robust targets of autoimmunity. We speculate that some specificities could be redundant (i.e., the CD8 T cells exist), and may even be expanded or primed by antigen-presenting cells cross-resenting $\beta$-cell proteins; but that the $\beta$ cell itself does not naturally process and present the cognate ligand. We would therefore advocate that as far as is possible, epitopes are verified by T-cell cloning and assays that show natural processing by $\beta$ cells, the most sensitive of which is probably in vitro cytotoxicity using human $\beta$ cells as targets.

\section{Islet Epitopes and Thymic Selection}

The thymus plays an important role in deletion of potentially autoreactive T cells. However, the presence of islet-specific $\mathrm{T}$ cells in the circulation of type 1 diabetes patients and healthy subjects indicates that the thymus is not capable of efficiently deleting all autoreactive $\mathrm{T}$ cells (Mathis and Benoist 2009). In addition to TCR affinity, a further influence on autoreactive CD8 T-cell escape from negative deletion is the strength of peptide binding to HLA, which influences occupancy and thus the strength of signal 1 provision. Based on experiences from pathogens, alloantigens, and tumor antigens, peptides binding with strong affinity to HLA are believed to be main epitopes for $\mathrm{T}$ cells. Yet, this rule of thumb most probably cannot apply to epitopes of autoreactive $T$ cells, because peptides binding with high affinity would drive HLA occupancy in the thymus and hence autoreactive T-cell deletion (Ouyang et al. 2006; Unger et al. 2011). Peptides with relatively weak affinity for HLA may be more relevant in the periphery during autoimmune disease precisely because relevant $\mathrm{T}$-cell specificities are allowed to escape. In the periphery, the density of expression of the index autoantigen may be much greater than in the thymus, enabling tolerance 
to be broken. Indeed, several recent reports point to unexpectedly low binding affinities of islet epitopes to HLA class I and II molecules (Ouyang et al. 2006; Unger et al. 2011). In the pancreas, where expression of antigens and epitopes is extended or amplified by the metabolic activity of the $\beta$ cell, peptides with weak affinity for HLA may become highly represented, leading to recognition by $\mathrm{T}$ cells that escaped thymic deletion.

\section{Posttranslational and Posttranscriptional Modifications}

Potentially, there are further mechanisms through which islet-specific T cells may escape negative deletion. One important example of emerging interest is that epitopes may never be presented in the thymus, simply because they are generated as neoantigens in the periphery as a result of posttranslational modifications (Diez et al. 2001; Mannering et al. 2005; Dogra et al. 2006). From our understanding of the pathogenesis of other autoimmune and inflammatory diseases it has become clear that proteins can be altered from their germline encoding sequence (which is thymically expressed) by a variety of cell biological modifications, and as a result give rise to new antigens against which tolerance does not exist. In rheumatoid arthritis, citrullination renders self-proteins subject to recognition by autoantibodies (van Venrooij and Pruijn 2000). In celiac disease, enzymatic deamidation of glutamine into glutamate by tissue transglutaminase increases the immunogenicity of gluten peptides (Arentz-Hansen et al. 2000). It is conceivable that similar or distinct modifications occur in the case of islet proteins creating immunogenic epitopes. The most notable proof of principle in the context of type 1 diabetes was provided by Mannering and colleagues (Mannering et al. 2005). T cells recognizing the proximal A chain of human insulin were isolated from pancreatic lymph nodes of subjects with type 1 diabetes. T-cell recognition was dependent on the formation of a vicinal disulfide bond between adjacent cysteine residues at A6 and A7, which did not alter binding of the peptide to HLA-DR4, implying a novel post- translational modification that is required for T-cell recognition of the insulin A chain.

Messenger RNA splice variation may also give rise to differential protein expression, distinguishing central (thymic) and peripheral (islet) proteomes. This has indeed been shown for the islet autoantigens IA-2 and IGRP (Diez et al. 2001; Dogra et al. 2006). Their expression in the pancreas is subject to posttranscriptional modifications, in which exon splicing, frame shifting, and truncations lead to changes in the original amino acid sequence. As a result, expression of neopeptide sequences in the pancreas, but not in the thymus, may generate epitopes for autoreactive CD8 T cells. Lack of full expression of the islet protein IGRP in the thymus may impair deletion of IGRP-specific CD8 T cells that are typically detectable in the peripheral blood of patients with type 1 diabetes (Velthuis et al. 2010).

\section{Polymorphisms in Islet Autoantigens}

It is also plausible that polymorphisms in islet autoantigens may contribute to immunogenicity and autoimmunity, but any relationship with disease is currently still poorly understood. The most documented polymorphism relates to insulin itself. Insulin gene transcription levels in the human thymus correlate with allelic variation at the promoter region (INS VNTRIDDM2) that acts as a genetic susceptibility locus for T1D (Pugliese et al. 1997; Chentoufi and Polychronakos 2002). VNTR alleles correlate with differential INS messenger RNA (mRNA) expression in the thymus where in contrast to the pancreas, protective class III variable number of tandem repeats (VNTRs) are associated with higher steady-state levels of INS mRNA expression. This may explain a protective effect of class III VNTRs: higher levels of class III VNTR-associated INS mRNA in the thymus leads to elevated levels of preproinsulin protein, thus enhancing central immune tolerance to preproinsulin.

With regard to polymorphisms in islet autoantigens themselves, a common nonsynonymous single-nucleotide polymorphism (SNP) in the SLC30A8 gene encoding ZnT8 influences ZnT8 autoantibody specificity in T1D (Wenzlau 
et al. 2007, 2008). This SNP affects amino acid 325 and lies within the region of highest ZnT8 autoantibody binding. Patients with type 1 diabetes react primarily with the $\mathrm{ZnT} 8$ variant that they carry. Any relevance of polymorphisms of islet autoantigens with regard to immunogenicity and diabetogenicity is unresolved, but it is conceivable that variants not expressed by islet allograft recipients could act as minor histocompatibility (allo-)antigens, increasing the potential to immunize the recipient against $\beta$-cell autoantigens.

\section{UTILIZING ISLET AUTOANTIGENS IN IMMUNE THERAPEUTIC TRIALS}

There are two settings of immunotherapy in which $\beta$-cell autoantigens could exert strong influence: either as therapeutics in their own right (antigen-specific immunotherapy; ASI) or as tools for the development of biomarkers and surrogates of therapeutic efficacy. ASI is now under development both as a potential preventive modality (Skyler et al. 2005; Staeva-Vieira et al. 2007; Thrower et al. 2009) and as a tolerance-inducing adjunct to combination therapeutics used in the intervention setting (Matthews et al. 2010). Recent contrasting results from two studies in the phase II intervention setting using GAD65 highlight the difficult pathway for the development of ASI (Ludvigsson et al. 2008; Wherrett et al. 2011). An issue that remains unresolved is whether a single or multiple autoantigens will be required. The answer may lie in the mechanism of action. ASI strategies that work predominantly through a peripheral deletion mechanism (e.g., using high doses and frequent administration) may need to cover multiple antigens that are targeted in the disease process. In contrast, ASI approaches that rely on induction of immune regulation (low dose, low frequency of administration) may be effective in restoring tolerance even when relatively few antigen specificities recognized by adaptive regulatory $\mathrm{T}$ cells (aTregs) are induced (Unger et al. 2009; Peakman and von Herrath 2010). In the context of these types of approach, it is easy to envisage the measurement of the autoantigen-specific immune re- sponse as a useful biomarker (e.g., GAD65 autoantibodies, GAD65-specific T-cell responses) of therapeutic effect. The immune phenotype of these responses (i.e., contribution of recognized T-cell subsets, cytokine, and chemokine profiles) and whether they represent induction of antigen-specific regulation or conversion of pathogenic effectors will also be important to establish. An untapped but critical area is that of adjuvant. The research community at large has perhaps been focused on adjuvants that promote immunogenicity, for example, in the context of cancer and infectious disease, and has largely ignored the flip side, namely, what is the requirement to render an antigen tolerogenic. The conjugation of GAD65 to alum is a first attempt at this, with the logic of attempting to divert proinflammatory $\mathrm{T}$ helper 1 cells by inducing counter-regulatory T helper 2 cells. The fact that the therapeutic approach as a whole failed to preserve $\beta$-cell function is only one of the issues to arise from the study conducted by Diabetes TrialNet (Wherrett et al. 2011). Important questions can be addressed in mechanistic studies, which are currently ongoing, that will establish whether at least the immunological strategy was successful in achieving immune diversion.

A final consideration is whether there is a disease heterogeneity that can be defined as being related to the autoantigens targeted. There is certainly evidence that autoantibody specificities can differ between patients, and to some extent are influenced by age and HLA genotype (and see Table 1) (Roep et al. 1996; Howson et al. 2011; Plagnol et al. 2011). In other respects, what is striking is the consistency with which the "usual suspect" autoantigens are targeted across the breadth of the disease. No unifying hypothesis has yet been elaborated to explain this, but it provides a very antigencentric view of the disease (Fig. 2).

\section{UTILIZING AUTOANTIGENS AS DISEASE BIOMARKERS}

As alluded to above, antigen-specific immunotherapy is a treatment modality that lends itself to the development of biomarkers that are based 
Table 1. Major autoantigens targeted by the adaptive immune system in type 1 diabetes: Tissue and species distribution

\begin{tabular}{|c|c|c|c|c|c|c|}
\hline \multirow[b]{2}{*}{ Autoantigen } & \multirow{2}{*}{$\begin{array}{c}\text { Tissue } \\
\text { distribution }\end{array}$} & \multicolumn{2}{|c|}{ Mice } & \multicolumn{2}{|c|}{ Men } & \multirow[b]{2}{*}{ Comments } \\
\hline & & AutoAbs & T cells & AutoAbs & T cells & \\
\hline Preproinsulin & $\beta$ cells, thymus & Yes & $\mathrm{CD} 4$ & Yes & $\begin{array}{l}\text { CD4, D8, } \\
\text { aTregs }\end{array}$ & $\begin{array}{l}\text { AAb affinity matters; CD8 T } \\
\text { cells lyse } \beta \text { cells in a } \\
\text { glucose-dependent manner; } \\
\text { genetically determined } \\
\text { variation in gene expression } \\
\text { in } \beta \text { cells vs. thymus }\end{array}$ \\
\hline $\begin{array}{l}\text { Glutamic } \\
\text { decarboxylase } 65 \\
\text { (GAD65) }\end{array}$ & $\begin{array}{l}\text { Islet cells, adrenal } \\
\text { gland, CNS, } \\
\text { neurons, testis, } \\
\text { ovary }\end{array}$ & No & $\mathrm{CD} 4$ & Yes & $\mathrm{CD} 4, \mathrm{CD} 8$ & $\begin{array}{l}\text { Not expressed in mouse } \beta \text { cells; } \\
\text { AAb associated with } \\
\text { HLA-DR3-DQ2 }\end{array}$ \\
\hline GAD67 & Islet cells, neurons & No & $\mathrm{CD} 4$ & Yes & $\mathrm{CD} 4$ & Not expressed in human $\beta$ cells \\
\hline $\begin{array}{l}\text { Tyrosine } \\
\text { phosphatase like } \\
\text { autoantigen or } \\
\text { insulinoma } \\
\text { antigen-2 (IA-2; } \\
\text { ICA512, PTPRN) }\end{array}$ & Islets & Yes & $\mathrm{CD} 4$ & Yes & $\mathrm{CD} 4, \mathrm{CD} 8$ & $\begin{array}{l}\text { AAb associated with } \\
\text { DR4-DQ8; alternative splice } \\
\text { variation; truncated variant: } \\
\text { ICA512 }\end{array}$ \\
\hline $\begin{array}{l}\text { IA- } 2 \beta \text { (Phogrin, } \\
\text { PTPRN2) }\end{array}$ & Islets & No & $\mathrm{CD} 4$ & Yes & $\mathrm{CD} 4$ & \\
\hline $\begin{array}{l}\text { Islet cell antigen-69 } \\
\quad \text { (ICA69) }\end{array}$ & $\begin{array}{l}\text { Pancreas, heart, } \\
\text { and brain }\end{array}$ & No & No & Yes & $\mathrm{CD} 4$ & $\begin{array}{l}\text { Inverse correlation between } \\
\text { AAb and T-cell responses; } \\
\text { AAb associated with } \\
\text { HLA-DR4, T-cell responses } \\
\text { with -DR3 }\end{array}$ \\
\hline $\begin{array}{l}\text { Zinc transporter-8 } \\
\quad(\mathrm{ZnT} 8)\end{array}$ & $\beta$ cells & & & & & Polymorphic \\
\hline Chromogranin A & $\begin{array}{l}\text { Neuroendocrine } \\
\text { cells }\end{array}$ & No & $\mathrm{CD} 4$ & No & ? & \\
\hline $\begin{array}{l}38 \mathrm{kDa} \text { granule } \\
\text { antigen }\end{array}$ & $\begin{array}{l}\text { Neuroendocrine } \\
\text { cells }\end{array}$ & No & ? & Yes & Yes & \\
\hline Peripherin & Neurons & No & $\mathrm{CD} 4$ & ? & ? & $\begin{array}{l}\text { No evidence of differential } \\
\text { recognition in human type } 1 \\
\text { diabetes }\end{array}$ \\
\hline $\begin{array}{l}\text { Islet amyloid } \\
\text { polypeptide } \\
\text { (ppIAPP) }\end{array}$ & Islets & No & $\mathrm{CD} 4$ & No & CD8 & $\begin{array}{l}\text { Immune responses not specific } \\
\text { for diabetes }\end{array}$ \\
\hline $\begin{array}{l}\text { Carboxypeptidase } \\
\text { H/E }\end{array}$ & $\begin{array}{r}\text { Neuroendocrine } \\
\text { cells; adrenals }\end{array}$ & No & No & Yes & No & \\
\hline $\begin{array}{l}\text { Heat shock protein } \\
60 \text { (hsp60) }\end{array}$ & $\begin{array}{l}\text { Ubiquitous } \\
\text { (mitochondria) }\end{array}$ & No & $\mathrm{CD} 4$ & No & $\mathrm{CD} 4$ & $\begin{array}{l}\text { Immune responses not disease } \\
\text { specific }\end{array}$ \\
\hline $\begin{array}{l}\text { IGRP; islet-specific } \\
\text { glucose-6- } \\
\text { phosphatase } \\
\text { catalytic subunit- } \\
\text { related protein }\end{array}$ & Islets & No & $\mathrm{CD} 8$ & No & CD8 & Alternative splice variation \\
\hline Sulfatide & Ubiquitous & No & No & Yes & $?$ & Anti-inflammatory properties \\
\hline Ganglioside & Ubiquitous & No & No & Yes & ? & \\
\hline
\end{tabular}

Abbreviations: Tregs, adaptive regulatory T cells; AAb, autoantibody. 
B.O. Roep and M. Peakman

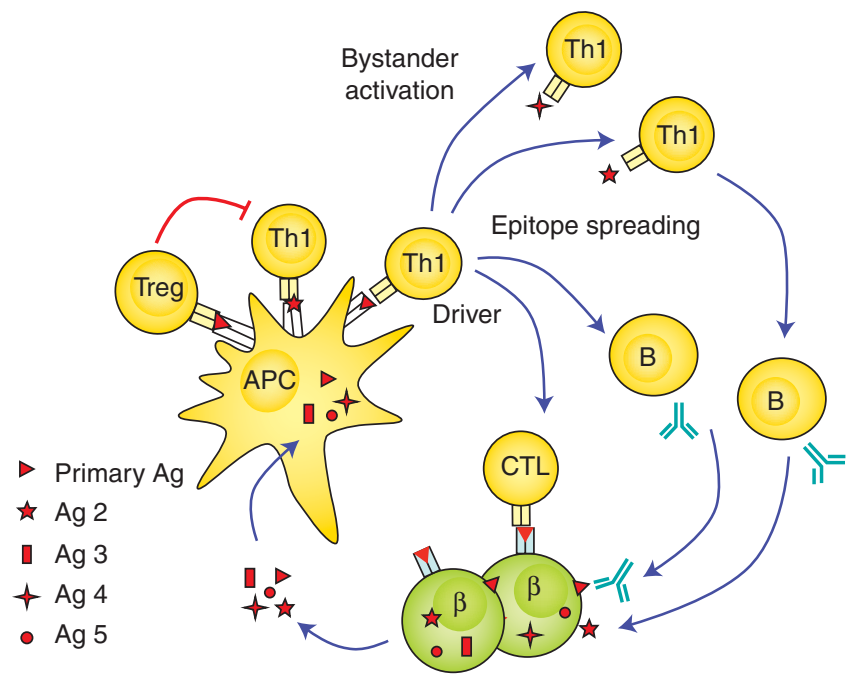

Figure 2. Loss of immunological tolerance to islet autoantigens. Islet proteins are taken up, processed, and presented by antigen-presenting cells (APC) to islet autoreactive T cells, leading to loss of tolerance. Additional islet autoreactive T cells may become activated (epitope spreading), which may contribute to $\beta$-cell destruction or represent nondestructive islet autoimmunity (bystander activation). Activation of islet autoreactive CD8 T cells may lead to direct recognition and destruction of pancreatic $\beta$ cells. CD4 T cells activate B cells to produce islet autoantibodies. Presentation of islet autoantigen to the immune system may also lead to activation of regulatory T cells (Tregs) leading to inhibition of proinflammtory islet autoimmunity.

around measuring autoantigen-specific T-cell responses. In this kind of approach, the autoantigen-specific immune responses that represent biomarkers of disease (e.g., GAD65 autoantibodies, GAD65-specific T-cell responses) have obvious potential as biomarkers of therapeutic effect, for example, when GAD65 is administered. In this context, GAD65-specific autoantibody titers rose dramatically and GAD65-specific T-cell responses emerged in the peripheral blood in association with the production of an array of cytokines in one recent report (Ludvigsson 2008). The immunological phenotype of the response (i.e., cytokine profile per cell, homing characteristics), and whether there was associated antigen-specific regulation will need to be examined in future studies, such as those conducted by Diabetes TrialNet (see above).

\section{FUTURE STRATEGIES}

The shape of the next 10-20 years of research on type 1 diabetes-related autoantigens can perhaps be viewed best through a series of questions.
What is the relevance of the multiple specificities and epitopes targeted by CD8 T cells? It remains to be established whether all epitopes identified to date via algorithm prediction, ELISPOT, humanized mouse immunization, and HLA multimer analysis are indeed relevant to $\beta$-cell death. If they are, then it would imply a somewhat overwhelming immune attack, begging the question as to why type 1 diabetes takes several years to develop. A concerted effort to clone CD8 T cells with relevant specificities, coupled with analysis of cytotoxicity against relevant targets is required.

What is the role of the autoantigen-specific CD4 T-cell response? Despite their presumed importance in the disease process, we still understand relatively little of the mechanisms through which $\beta$-cell-specific CD4 T cells contribute to disease. One of the exciting areas to emerge is that of the posttranslational modification of autoantigens, and the mechanisms through which this could break CD4 T-cell tolerance. This could be complemented by a greater effort to clone and define the function 
of $\beta$-cell-specific CD4 T cells, possibly using newly devised strategies (Geiger et al. 2009).

What does the $T$-cell receptor repertoire tell us about disease? With the emergence of strategies for deep and broad sequencing of the T-cell receptor, studies will need to address the question as to whether this presents an alternative and powerful systems approach to defining novel targets of the T-cell response, that do not presuppose the identity of the autoantigen or HLA molecule involved. This could be especially powerful when applied to immune infiltrates from the pancreas of post mortem samples from recent-onset patients with type 1 diabetes, or, more powerful still, from those in the process of developing the disease.

Are further antigen specificities required? There can be little doubt that there are further $\beta$-cell autoantigens to be discovered, but do we need them? The addition of anti-ZnT8 autoantibodies to the portfolio has undoubtedly provided a further opportunity for subcategorization and risk assignment. Additional antigens may thus provide further stand-alone biomarkers and, in the context of antigen-specific immunotherapy, further codiagnostics or linked biomarkers.

\section{SUMMARY}

The identification of $\beta$-cell proteins as autoantigens was perhaps the defining moment for type 1 diabetes as a disease, because it represented the first evidence that placed the disease in the pathogenetic category of autoimmunity. Autoantigens have since been exploited in many diverse scientific and clinical endeavors: as tools to understand pathogenesis, to devise biomarkers, to classify and subclassify, to predict, and, more recently, to treat or prevent. In the future, autoantigens as tools may even broaden our $\beta$-cell imaging horizons. We suspect that there is much more to come in this rich vein of research.

\section{ACKNOWLEDGMENTS}

M.P. is supported by the UK Department of Health via the National Institute for Health Research (NIHR) comprehensive Biomedical Re- search Centre award to Guy's and St Thomas' NHS Foundation Trust in partnership with King's College London, and the Juvenile Diabetes Research Foundation (JDRF: 7-2005-877 and 1-2007-1803). B.O.R. is supported by the Dutch Diabetes Research Foundation, a VICI award from ZonMW, and by the JDRF. Both are supported by the EU FP7 EU Framework 7 Large-Scale Focused Collaborative Research Project on Natural Immunomodulators as Novel Immunotherapies for Type 1 Diabetes (NAIMIT).

\section{REFERENCES}

Achenbach P, Bonifacio E, Koczwara K, Ziegler AG. 2005. Natural history of type 1 diabetes. Diabetes 54 (Suppl 2): $S 25-S 31$.

Anderson MS, Venanzi ES, Klein L, Chen Z, Berzins SP, Turley SJ, von Boehmer H, Bronson R, Dierich A, Benoist C, et al. 2002. Projection of an immunological self shadow within the thymus by the aire protein. Science 298: 1395-1401.

Arden SD, Roep BO, Neophytou PI, Usac EF, Duinkerken G, de Vries RR, Hutton JC. 1996. Imogen 38: A novel 38-kD islet mitochondrial autoantigen recognized by $\mathrm{T}$ cells from a newly diagnosed type 1 diabetic patient. J Clin Invest 97: 551-561.

Arentz-Hansen H, Körner R, Molberg O, Quarsten H, Vader W, Kooy YM, Lundin KE, Koning F, Roepstorff P, Sollid LM, et al. 2000. The intestinal T cell response to $\alpha$-gliadin in adult celiac disease is focused on a single deamidated glutamine targeted by tissue transglutaminase. J Exp Med 191: 603-612.

Arif S, Tree TI, Astill TP, Tremble JM, Bishop AJ, Dayan CM, Roep BO, Peakman M. 2004. Autoreactive T cell responses show proinflammatory polarization in diabetes but a regulatory phenotype in health. J Clin Invest 113: 451-463.

Atkinson MA, Maclaren NK. 1993. Islet cell autoantigens in insulin-dependent diabetes. J Clin Invest 92: 1608-1616.

Atkinson MA, Kaufman DL, Campbell L, Gibbs KA, Shah SC, Bu DF, Erlander MG, Tobin AJ, Maclaren NK. 1992. Response of peripheral-blood mononuclear cells to glutamate decarboxylase in insulin-dependent diabetes. Lancet 339: 458-459.

Baekkeskov S, Aanstoot HJ, Christgau S, Reetz A, Solimena M, Cascalho M, Folli F, Richter-Olesen H, De Camilli P. 1990. Identification of the $64 \mathrm{~K}$ autoantigen in insulindependent diabetes as the GABA-synthesizing enzyme glutamic acid decarboxylase. Nature 347: 151-156.

Bottazzo GF, Florin-Christensen A, Doniach D. 1974. Isletcell antibodies in diabetes mellitus with autoimmune polyendocrine deficiencies. Lancet 2: 1279-1283.

Bottazzo GF, Dean BM, McNally JM, MacKay EH, Swift PG, Gamble DR. 1985. In situ characterization of autoimmune phenomena and expression of HLA molecules in the pancreas in diabetic insulitis. $N$ Engl J Med 313: $353-360$. 
B.O. Roep and M. Peakman

Brooks-Worrell BM, Starkebaum GA, Greenbaum C, Palmer JP. 1996. Peripheral blood mononuclear cells of insulin-dependent diabetic patients respond to multiple islet cell proteins. J Immunol 157: 5668-5674.

Chentoufi AA, Polychronakos C. 2002. Insulin expression levels in the thymus modulate insulin-specific autoreactive T-cell tolerance: The mechanism by which the IDDM2 locus may predispose to diabetes. Diabetes 51: 1383-1390.

Dang M, Rockell J, Wagner R, Wenzlau JM, Yu L, Hutton JC, Gottlieb PA, Davidson HW. 2011. Human type 1 diabetes is associated with $\mathrm{T}$ cell autoimmunity to zinc transporter 8. J Immunol 186: 6056-6063.

Delong T, Baker RL, Reisdorph N, Reisdorph R, Powell RL, Armstrong M, Barbour G, Bradley B, Haskins K. 2011. Islet amyloid polypeptide is a target antigen for diabetogenic CD4 ${ }^{+} \mathrm{T}$ cells. Diabetes 60: 2325-2330.

Diez J, Park Y, Zeller M, Brown D, Garza D, Ricordi C, Hutton J, Eisenbarth GS, Pugliese A. 2001. Differential splicing of the IA- 2 mRNA in pancreas and lymphoid organs as a permissive genetic mechanism for autoimmunity against the IA-2 type 1 diabetes autoantigen. Diabetes 50: $895-900$.

Di Lorenzo TP, Peakman M, Roep BO. 2007. Translational mini-review series on type 1 diabetes: Systematic analysis of T cell epitopes in autoimmune diabetes. Clin Exp Immunol 148: 1-16.

Dogra RS, Vaidyanathan P, Prabakar KR, Marshall KE, Hutton JC, Pugliese A. 2006. Alternative splicing of G6PC2, the gene coding for the islet-specific glucose-6-phosphatase catalytic subunit-related protein (IGRP), results in differential expression in human thymus and spleen compared with pancreas. Diabetologia 49: 953-957.

Durinovic-Bello I, Hummel M, Ziegler AG. 1996. Cellular immune response to diverse islet cell antigens in IDDM. Diabetes 45: 795-800.

Eizirik DL, Colli ML, Ortis F. 2009. The role of inflammation in insulitis and $\beta$-cell loss in type 1 diabetes. Nat Rev Endocrinol 5: 219-226.

Faideau B, Briand JP, Lotton C, Tardivel I, Halbout P, Jami J, Elliott JF, Krief P, Muller S, Boitard C, et al. 2004. Expression of preproinsulin-2 gene shapes the immune response to preproinsulin in normal mice. J Immuno 172: $25-33$.

Geiger R, Duhen T, Lanzavecchia A, Sallusto F. 2009. Human naive and memory $\mathrm{CD} 4^{+} \mathrm{T}$ cell repertoires specific for naturally processed antigens analyzed using libraries of amplified T cells. J Exp Med 206: 1525-1534.

Han B, Serra P, Amrani A, Yamanouchi J, Marée AF, Edelstein-Keshet L, Santamaria P. 2005. Prevention of diabetes by manipulation of anti-IGRP autoimmunity: High efficiency of a low-affinity peptide. Nat Med 11: 645-652.

Harrison LC. 1992. Islet cell antigens in insulin-dependent diabetes: Pandora's box revisited. Immunol Today 13: 348-352.

Haskins K, Portas M, Bergman B, Lafferty K, Bradley B. 1989. Pancreatic islet-specific T-cell clones from nonobese diabetic mice. Proc Natl Acad Sci 86: 8000-8004.

Hawkes CJ, Schloot NC, Marks J, Willemen SJ, Drijfhout JW, Mayer EK, Christie MR, Roep BO. 2000. T-cell lines reactive to an immunodominant epitope of the tyrosine phosphatase-like autoantigen IA-2 in type 1 diabetes. Diabetes 49: 356-366.

Howson JM, Stevens H, Smyth DJ, Walker NM, Chandler KA, Bingley PJ, Todd JA. 2011. Evidence that HLA class I and II associations with type 1 diabetes, autoantibodies to GAD and autoantibodies to IA-2, are distinct. Diabetes 60: $2635-2644$.

Karlsen AE, Hagopian WA, Petersen JS, Boel E, Dyrberg T, Grubin CE, Michelsen BK, Madsen OD, Lernmark A. 1992. Recombinant glutamic acid decarboxylase (representing the single isoform expressed in human islets) detects IDDM-associated 64,000-M(r) autoantibodies. Diabetes 41: 1355-1359.

Kash SF, Condie BG, Baekkeskov S. 1999. Glutamate decarboxylase and GABA in pancreatic islets: Lessons from knock-out mice. Horm Metab Res 31: 340-344.

Kaufman DL, Clare-Salzler M, Tian J, Forsthuber T, Ting GS, Robinson P, Atkinson MA, Sercarz EE, Tobin AJ, Lehmann PV. 1993. Spontaneous loss of T-cell tolerance to glutamic acid decarboxylase in murine insulindependent diabetes. Nature 366: 69-72.

Kawasaki E, Eisenbarth GS, Wasmeier C, Hutton JC. 1996. Autoantibodies to protein tyrosine phosphatase-like proteins in type I diabetes. Overlapping specificities to phogrin and ICA512/IA-2. Diabetes 45: 1344-1349.

Ludvigsson J, Faresjö M, Hjorth M, Axelsson S, Chéramy M, Pihl M, Vaarala O, Forsander G, Ivarsson S, Johansson C, et al. 2008. GAD treatment and insulin secretion in recent-onset type 1 diabetes. $N$ Engl J Med 359: 19091920.

Mallone R, Martinuzzi E, Blancou P, Novelli G, Afonso G, Dolz M, Bruno G, Chaillous L, Chatenoud L, Bach JM, et al. 2007. CD $8^{+} \mathrm{T}$-cell responses identify $\beta$-cell autoimmunity in human type 1 diabetes. Diabetes 56: 613-621.

Mannering SI, Harrison LC, Williamson NA, Morris JS, Thearle DJ, Jensen KP, Kay TW, Rossjohn J, Falk BA, Nepom GT, et al. 2005. The insulin A-chain epitope recognized by human $\mathrm{T}$ cells is posttranslationally modified. J Exp Med 202: 1191-1197.

Martin S, Kardorf J, Schulte B, Lampeter EF, Gries FA, Melchers I, Wagner R, Bertrams J, Roep BO, Pfützner A. 1995. Autoantibodies to the islet antigen ICA69 occur in IDDM and in rheumatoid arthritis. Diabetologia 38: 351-355.

Mathis D, Benoist C. 2009. Aire. Annu Rev Immunol 27: 287-312.

Matthews JB, Staeva TP, Bernstein PL, Peakman M, von Herrath M. 2010. Developing combination immunotherapies for type 1 diabetes: Recommendations from the ITN-JDRF Type 1 Diabetes Combination Therapy Assessment Group. Clin Exp Immunol 160: 176-184.

Miyazaki I, Gaedigk R, Hui MF, Cheung RK, Morkowski J, Rajotte RV, Dosch HM. 1994. Cloning of human and rat p69 cDNA, a candidate autoimmune target in type 1 diabetes. Biochim Biophys Acta 1227: 101-104.

Moriyama H, Abiru N, Paronen J, Sikora K, Liu E, Miao D, Devendra D, Beilke J, Gianani R, Gill RG, et al. 2003. Evidence for a primary islet autoantigen (preproinsulin 1) for insulitis and diabetes in the nonobese diabetic mouse. Proc Natl Acad Sci 100: 10376-10381.

Naik RG, Beckers C, Wentwoord R, Frenken A, Duinkerken G, Brooks-Worrell B, Schloot NC, Palmer JP, Roep BO. 
2004. Precursor frequencies of T-cells reactive to insulin in recent onset type 1 diabetes mellitus. J Autoimmun 23: $55-61$

Neophytou PI, Roep BO, Arden SD, Muir EM, Duinkerken G, Kallan A, de Vries RR, Hutton JC. 1996. T-cell epitope analysis using subtracted expression libraries (TEASEL): Application to a $38-\mathrm{kDA}$ autoantigen recognized by $\mathrm{T}$ cells from an insulin-dependent diabetic patient. Proc Natl Acad Sci 93: 2014-2018.

Ouyang Q, Standifer NE, Qin H, Gottlieb P, Verchere CB, Nepom GT, Tan R, Panagiotopoulos C. 2006. Recognition of HLA class I-restricted $\beta$-cell epitopes in type 1 diabetes. Diabetes 55: 3068-3074.

Panina-Bordignon P, Lang R, van Endert PM, Benazzi E, Felix AM, Pastore RM, Spinas GA, Sinigaglia F. 1995. Cytotoxic $\mathrm{T}$ cells specific for glutamic acid decarboxylase in autoimmune diabetes. J Exp Med 181: 1923-1927.

Payton MA, Hawkes CJ, Christie MR. 1995. Relationship of the 37,000- and 40,000-M(r) tryptic fragments of islet antigens in insulin-dependent diabetes to the protein tyrosine phosphatase-like molecule IA-2 (ICA512). J Clin Invest 96: 1506-1511.

Peakman M, von Herrath M. 2010. Antigen-specific immunotherapy for type 1 diabetes: Maximizing the potential. Diabetes 59: 2087-2093.

Peakman M, Stevens EJ, Lohmann T, Narendran P, Dromey J, Alexander A, Tomlinson AJ, Trucco M, Gorga JC, Chicz RM. 1999. Naturally processed and presented epitopes of the islet cell autoantigen IA-2 eluted from HLA-DR4. $J$ Clin Invest 104: 1449-1457.

Peakman M, Tree TI, Endl J, van Endert P, Atkinson MA, Roep BO. 2001. Characterization of preparations of GAD65, proinsulin, and the islet tyrosine phosphatase IA-2 for use in detection of autoreactive T-cells in type 1 diabetes: Report of phase II of the Second International Immunology of Diabetes Society Workshop for Standardization of T-Cell Assays in Type 1 Diabetes. Diabetes 50: $1749-1754$.

Pinkse GG, Tysma OH, Bergen CA, Kester MG, Ossendorp F, van Veelen PA, Keymeulen B, Pipeleers D, Drijfhout JW, Roep BO. 2005. Autoreactive CD8 T cells associated with $\beta$-cell destruction in type 1 diabetes. Proc Natl Acad Sci 102: $18425-18430$.

Plagnol V, Howson JM, Smyth DJ, Walker N, Hafler JP, Wallace C, Stevens H, Jackson L, Simmonds MJ, et al. Type 1 Diabetes Genetics Consortium, 2011. Genome-wide association analysis of autoantibody positivity in type 1 diabetes cases. PLoS Genet 7: e1002216.

Pugliese A, Zeller M, Fernandez A Jr, Zalcberg LJ, Bartlett RJ, Ricordi C, Pietropaolo M, Eisenbarth GS, Bennett ST, Patel DD. 1997. The insulin gene is transcribed in the human thymus and transcription levels correlated with allelic variation at the INS VNTR-IDDM2 susceptibility locus for type 1 diabetes. Nat Genet 15: 293-297.

Roep BO, Arden SD, De Vries RR, Hutton JC. 1990. T-cell clones from a type-1 diabetes patient respond to insulin secretory granule proteins. Nature 345: 632-634.

Roep BO, Kallan AA, Hazenbos WL, Bruining GJ, Bailyes EM, Arden SD, Hutton JC, de Vries RR. 1991. T-cell reactivity to $38 \mathrm{kD}$ insulin-secretory-granule protein in patients with recent-onset type 1 diabetes. Lancet 337 : 1439-1441.
Roep BO, Duinkerken G, Schreuder GM, Kolb H, de Vries RR, Martin S. 1996. HLA-associated inverse correlation between $\mathrm{T}$ cell and antibody responsiveness to islet autoantigen in recent-onset insulin-dependent diabetes mellitus. Eur J Immunol 26: 1285-1289.

Roep BO, Atkinson MA, van Endert PM, Gottlieb PA, Wilson SB, Sachs JA. 1999. Autoreactive T cell responses in insulin-dependent (type 1) diabetes mellitus. Report of the first international workshop for standardization of T cell assays. J Autoimmun 13: 267-282.

Roep BO, Atkinson M, von Herrath M. 2004. Satisfaction (not) guaranteed: Re-evaluating the use of animal models of type 1 diabetes. Nat Rev Immunol 4: 989-997.

Roep BO, Kleijwegt FS, van Halteren AG, Bonato V, Boggi U, Vendrame F, Marchetti P, Dotta F. 2010. Islet inflammation and CXCL10 in recent-onset type 1 diabetes. Clin Exp Immunol 159: 338-343.

Schloot NC, Roep BO, Wegmann D, Yu L, Chase HP, Wang T, Eisenbarth GS. 1997. Altered immune response to insulin in newly diagnosed compared to insulin-treated diabetic patients and healthy control subjects. Diabetologia 40: $564-572$.

Schloot NC, Meierhoff G, Karlsson Faresjö M, Ott P, Putnam A, Lehmann P, Gottlieb P, Roep BO, Peakman M, Tree T. 2003. Comparison of cytokine ELISpot assay formats for the detection of islet antigen autoreactive $\mathrm{T}$ cells. Report of the third immunology of diabetes society T-cell workshop. J Autoimmun 21: 365-376.

Schloot NC, Meierhoff G, Lengyel C, Vándorfi G, Takács J, Pánczél P, Barkai L, Madácsy L, Oroszlán T, Kovács $\mathrm{P}$, et al. 2007. Effect of heat shock protein peptide DiaPep277 on beta-cell function in paediatric and adult patients with recent-onset diabetes mellitus type 1: Two prospective, randomized, double-blind phase II trials. Diabetes Metab Res Rev 23: 276-285.

Skowera A, Ellis RJ, Varela-Calviño R, Arif S, Huang GC, Van-Krinks C, Zaremba A, Rackham C, Allen IS, Tree TI, et al. 2008. CTLs are targeted to kill $\beta$ cells in patients with type 1 diabetes through recognition of a glucoseregulated preproinsulin epitope. J Clin Invest 118: 3390-3402.

Skyler JS, Krischer JP, Wolfsdorf J, Cowie C, Palmer JP, Greenbaum C, Cuthbertson D, Rafkin-Mervis LE, Chase HP, Leschek E. 2005. Effects of oral insulin in relatives of patients with type 1 diabetes: The Diabetes Prevention Trial-Type 1. Diabetes Care 28: 1068-1076.

Stadinski BD, Delong T, Reisdorph N, Reisdorph R, Powell RL, Armstrong M, Piganelli JD, Barbour G, Bradley B, Crawford F, et al. 2010. Chromogranin A is an autoantigen in type 1 diabetes. Nat Immunol 11: 225-231.

Staeva-Vieira T, Peakman M, von Herrath M. 2007. Translational mini-review series on type 1 diabetes: Immunebased therapeutic approaches for type 1 diabetes. Clin Exp Immunol 148: 17-31.

Steck AK, Johnson K, Barriga KJ, Miao D, Yu L, Hutton JC, Eisenbarth GS, Rewers MJ. 2011. Age of islet autoantibody appearance and mean levels of insulin, but not GAD or IA-2 autoantibodies, predict age of diagnosis of type 1 diabetes: Diabetes autoimmunity study in the young. Diabetes Care 34: 1397-1399. 
B.O. Roep and M. Peakman

Stewart TA, Hultgren B, Huang X, Pitts-Meek S, Hully J, MacLachlan NJ. 1993. Induction of type I diabetes by interferon- $\alpha$ in transgenic mice. Science 260: 1942-1946.

Takaki T, Marron MP, Mathews CE, Guttmann ST, Bottino R, Trucco M, DiLorenzo TP, Serreze DV. 2006. HLA$\mathrm{A}^{*}$ 0201-restricted $\mathrm{T}$ cells from humanized NOD mice recognize autoantigens of potential clinical relevance to type 1 diabetes. J Immunol 176: 3257-3265.

Thrower SL, James L, Hall W, Green KM, Arif S, Allen JS, Van-Krinks C, Lozanoska-Ochser B, Marquesini L, Brown S, et al. 2009. Proinsulin peptide immunotherapy in type diabetes: Report of a first-in-man phase I safety study. Clin Exp Immunol 155: 156-165.

Tisch R, Yang XD, Singer SM, Liblau RS, Fugger L, McDevitt HO. 1993. Immune response to glutamic acid decarboxylase correlates with insulitis in non-obese diabetic mice. Nature 366: 72-75.

Toma A, Haddouk S, Briand JP, Camoin L, Gahery H, Connan F, Dubois-Laforgue D, Caillat-Zucman S, Guillet JG Carel JC, et al. 2005. Recognition of a subregion of human proinsulin by class I-restricted T cells in type 1 diabetic patients. Proc Natl Acad Sci 102: 10581-10586.

Toma A, Laïka T, Haddouk S, Luce S, Briand JP, Camoin L, Connan F, Lambert M, Caillat-Zucman S, Carel JC, et al. 2009. Recognition of human proinsulin leader sequence by class I-restricted T-cells in HLA-A*0201 transgenic mice and in human type 1 diabetes. Diabetes 58: 394 402.

Trudeau JD, Kelly-Smith C, Verchere CB, Elliott JF, Dutz JP, Finegood DT, Santamaria P, Tan R. 2003. Prediction of spontaneous autoimmune diabetes in NOD mice by quantification of autoreactive $\mathrm{T}$ cells in peripheral blood. J Clin Invest 111: 217-223.

Trudeau JD, Chandler T, Soukhatcheva G, Verchere CB, Tan R. 2007. Prospective prediction of spontaneous but not recurrent autoimmune diabetes in the non-obese diabetic mouse. Diabetologia 50: 1015-1023.

Unger WW, Laban S, Kleijwegt FS, van der Slik AR, Roep BO. 2009. Induction of Treg by monocyte-derived DC modulated by vitamin D3 or dexamethasone: Differential role for PD-L1. Eur J Immunol 39: 3147-3159.

Unger WW, Velthuis J, Abreu JR, Laban S, Quinten E, Kester MG, Reker-Hadrup S, Bakker AH, Duinkerken G, Mulder
A, et al. 2011. Discovery of low-affinity preproinsulin epitopes and detection of autoreactive CD8 T-cells using combinatorial MHC multimers. J Autoimmun doi: 10.1016/ j.jaut.2011.05.012.

van Venrooij WJ, Pruijn GJ. 2000. Citrullination: A small change for a protein with great consequences for rheumatoid arthritis. Arthritis Res 2: 249-251.

Velthuis JH, Unger WW, Abreu JR, Duinkerken G, Franken K, Peakman M, Bakker AH, Reker-Hadrup S, Keymeulen B, Drijfhout JW, et al. 2010. Simultaneous detection of circulating autoreactive $\mathrm{CD} 88^{+}$T-cells specific for different islet cell-associated epitopes using combinatorial MHC multimers. Diabetes 59: 1721-1730.

Wegmann DR, Norbury-Glaser M, Daniel D. 1994. Insulinspecific $\mathrm{T}$ cells are a predominant component of islet infiltrates in pre-diabetic NOD mice. Eur J Immunol 24: $1853-1857$.

Wenzlau JM, Juhl K, Yu L, Moua O, Sarkar SA, Gottlieb P, Rewers M, Eisenbarth GS, Jensen J, Davidson HW, et al. 2007. The cation efflux transporter ZnT8 (Slc30A8) is a major autoantigen in human type 1 diabetes. Proc Natl Acad Sci 104: 17040-17045.

Wenzlau JM, Liu Y, Yu L, Moua O, Fowler KT, Rangasamy S, Walters J, Eisenbarth GS, Davidson HW, Hutton JC. 2008. A common nonsynonymous single nucleotide polymorphism in the SLC30A8 gene determines ZnT8 autoantibody specificity in type 1 diabetes. Diabetes 57: 2693 2697.

Wenzlau JM, Walter M, Gardner TJ, Frisch LM, Yu L, Eisenbarth GS, Ziegler AG, Davidson HW, Hutton JC. 2010. Kinetics of the post-onset decline in zinc transporter 8 autoantibodies in type 1 diabetic human subjects. J Clin Endocrinol Metab 95: 4712-4719.

Wherrett DK, Bundy B, Becker DJ, DiMeglio LA, Gitelman SE, Goland R, Gottlieb PA, Greenbaum CJ, Herold KC, Marks JB, et al. 2011. Antigen-based therapy with glutamic acid decarboxylase (GAD) vaccine in patients with recent-onset type 1 diabetes: A randomised double-blind trial. Lancet 378: 319-327.

Willcox A, Richardson SJ, Bone AJ, Foulis AK, Morgan NG. 2009. Analysis of islet inflammation in human type 1 diabetes. Clin Exp Immunol 155: 173-181. 


\title{
$\&_{\mathrm{CSH}}^{\infty} \&$ Cold Spring Harbor

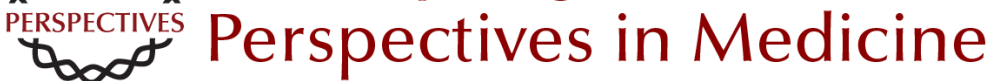

\section{Antigen Targets of Type 1 Diabetes Autoimmunity}

\author{
Bart O. Roep and Mark Peakman
}

Cold Spring Harb Perspect Med 2012; doi: 10.1101/cshperspect.a007781 originally published online January 18, 2012

\section{Subject Collection Type I Diabetes}

The Pathogenesis and Natural History of Type 1 Diabetes

Mark A. Atkinson

Do MHCII-Presented Neoantigens Drive Type 1

Diabetes and Other Autoimmune Diseases?

Philippa Marrack and John W. Kappler

Clinical Immunologic Interventions for the

Treatment of Type 1 Diabetes

Lucienne Chatenoud, Katharina Warncke and

Anette-G. Ziegler

Update on Islet Transplantation

Michael McCall and A.M. James Shapiro

Immunologic and Metabolic Biomarkers of $\beta$-Cell

Destruction in the Diagnosis of Type 1 Diabetes Jasmin Lebastchi and Kevan C. Herold

Advancing Animal Models of Human Type 1

Diabetes by Engraftment of Functional Human

Tissues in Immunodeficient Mice

Michael A. Brehm, Alvin C. Powers, Leonard D.

Shultz, et al.

Breakdown in Peripheral Tolerance in Type 1

Diabetes in Mice and Humans

Lukas T. Jeker, Hélène Bour-Jordan and Jeffrey $A$. Bluestone

Antigen-Specific Therapeutic Approaches in Type 1 Diabetes

Xavier Clemente-Casares, Sue Tsai, Carol Huang, et al.
Humoral Autoimmunity in Type 1 Diabetes:

Prediction, Significance, and Detection of Distinct

Disease Subtypes

Massimo Pietropaolo, Roberto Towns and George

S. Eisenbarth

Endoplasmic Reticulum Stress, Pancreatic $\beta$-Cell

Degeneration, and Diabetes

Feroz R. Papa

Islet Autoantigens: Structure, Function,

Localization, and Regulation

Peter Arvan, Massimo Pietropaolo, David Ostrov, et al.

Environmental Triggers of Type 1 Diabetes Mikael Knip and Olli Simell

Generating $\beta$ Cells from Stem Cells--The Story So

Far

Matthias Hebrok

Antigen Targets of Type 1 Diabetes Autoimmunity Bart O. Roep and Mark Peakman

Connecting Type 1 and Type 2 Diabetes through Innate Immunity Justin I. Odegaard and Ajay Chawla

The Hygiene Hypothesis: An Explanation for the Increased Frequency of Insulin-Dependent Diabetes Jean-François Bach and Lucienne Chatenoud

For additional articles in this collection, see http://perspectivesinmedicine.cshlp.org/cgi/collection/ 